\title{
Livelihood strategy of ethnic minority farmers - Ta OI ethnic minority case study, A Luoi district, Thua Thien Hue province - Vietnam
}

\author{
Nguyen Duc Huu - Vietnam Trade Union University
}

Email: $\underline{\text { huund@ @dhcd.edu.vn }}$

\begin{abstract}
Abtract:
Entering the 21 st century, the world is emerging human and human psychology, human personality, human intellect, human potential, human resources. All countries place people at the center of the socio-economic development strategy in the first decade of the new century. Developing people and human resources with sufficient talent and virtue to achieve goals, rich people, strong countries, a fair, democratic and civilized society. This article focuses on understanding human resources in the area of health and the impact of this resource on traditional and current livelihoods. Thereby, the authors propose a number of solutions to improve human factor capacity in the livelihood development of Ta Oi people in A Luoi district, Thua Thien Hue province.

Key word: Livelihood, human capital, health, A Luoi district
\end{abstract}

\section{Introduction}

A Net is a western upland district of Thua Thien Hue Province with a natural area of about ${ }^{1,225 \mathrm{~km} 2 ;}$ where there is an important strategiclocation of economy, defense and security of Thua Thien Hue province and the North Central region, which is an advantage for the district to expand economic and cultural cooperation with laos and other countries in the Region. Ethnic minorities in A Net district have a long history of formation along with the history of development of ethnic minorities in the country, with many ethnic groups living together to create their own cultural identity of each ethnic group. They live scattered in many small gathering points, villages far from each other, must go through many streams and hills. However, due to the long-standing state of community and intercrotation, the peoples here have had solidarity of economic and cultural exchanges and had close ties with the Kinh people in the field and the Kinh people interspersed in the area.

Human capital: Simply understood, human capital is the result of the process of investing in activities to improve personal productivity such as education, health, on-site training .... According to Mincer Jacob, human capital is the same as tangible capital, wanting it, people have to invest to accumulate through training education at work and give it back to its owner with income [Bui Quang Binh, 2009]. In this article, human 
capital is analyzed from health characteristics that affect the life of ta oi people, A Net district, Thua Thien Hue province.

Livelihoods: The term livelihood is a relatively new concept, reflecting the picture of summing up the ways of making a living of people or communities. Access to livelihoods will give communities as well as external support people the opportunity to escape poverty, adapt to social natural conditions, and make better changes for themselves and for the next generations. A livelihood consists of potential capacity, property (shops, resources, land, roads) and activities needed to make a living.

CRD shares the concept of sustainable livelihoods and livelihoods put in place by DFIT, so livelihoods are understood as: "Gather all the resources and abilities that people have, combined with the decisions and activities they make to make a living as well as to achieve their goals and aspirations; The resources of livelihoods include: Human capital, material capital, natural capital, financial capital, social capital"[CRD, 2006].

\section{Data and Methodology}

Analyzing the livelihoods of farmers who had their agricultural land revoked during the (IAU)process, the study was conducted with 300 dosing samples and 20 quasiquasi-quasi-quasi-samples as the number of households recovered by the government between 2008 and 2013. The study analyzed the livelihood characteristics of farmers before and after the land was recovered. The study shows the link between livelihood capital, livelihood model and current livelihood outcomes.

In order to determine the impact of agricultural land recovery on farmers' livelihoods, a comparative analysis based on quadative results among land-recovered and non-recovered households was described in detail by the study. It answers the question of whether land recovery has a significant impact on farmers' livelihoods and what is a direct impact on the transformation of their livelihoods.

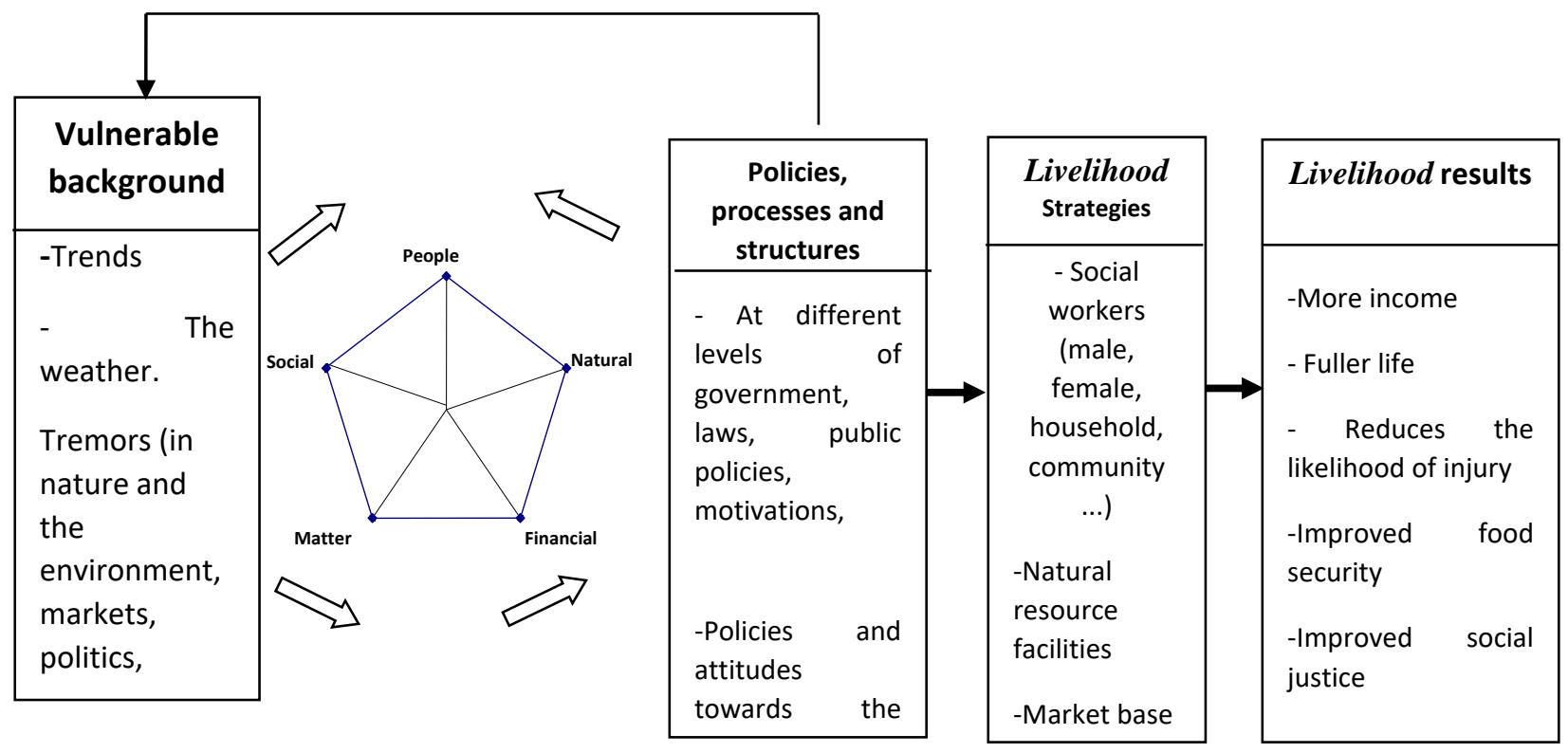




\section{Sustainable Livelihood Framework Source: DFID (2001) \\ Mof livelihood cells of the group of farmers who lost land within the survey range are divided into 3 basicforms. \\ - The livelihood model group is based mainty on agricultural land (the remaining land area after being recovered or leased new land): rice cultivation, crops, livestock, poultry .... \\ - Mixed livelihood model group:income of farmers based in part from agriculturalactivities (rice cultivation, crops, livestock, poultry) combined with non-agricultural activities (small trade, free labor..) \\ - The livelihood model group is based mainly on non-agricultural occupationsand jobs: Working as workers in technologyparks, trading, services, free employment ...}

Livelihood outcome: as a result of the impact between independent variables and dependent variables. Livelihood results in the diss currently expressed in such as income, employment status and living conditions.

The article uses the statistics and quantities of A Luoi district, Thua Thien Hue province - Vietnam

\section{Result}

Income represents every other measure of human development that has not been reflected in the measures of longevity or knowledge. When the average income reaches a certain level it is possible to satisfy basic human needs. In addition, income also reflects the effective nature of the labor process reflected in the general living rate of the population.

"The overall income of the people here (A Dut commune) averages about 8 - 8.5 million / person / year and this is also the per capita income of the whole district, with this income is very low, less than half the overall average of the wholeprovince". Male, government employee of A Dut commune, A Luoi district, Hue Province.

The main income areas of Ta Oi households include: agriculture (accounting for a large proportion), forestry, fishery, part-time work, japanese wages, benefits, pensions and deposits sent by members to work far away ... In addition, the income level is obtained by a number of employees working in enterprises in the district, the number of non-agricultural and fishery individual economic opportunities. A Ta Oi household in A Luoi often has many generations of living, many working ages and in different fields, mainly agriculture. The main agricultural economic activities include the cultivation of rice, maize and some other agricultural products. Although the income of households comes from many different sectors, agricultural activities play a leading role. Therefore, 
it is necessary to have policies to structure the workforce in the fields of agricultural production to ensure sustainable development.

Low income level is the general situation in the economic picture of A Luoi district. Aware of this issue, in recent years, the district has made feasible policies to raise people's incomes, focusing on poverty alleviation. Therefore, the proportion of poor households in the district has decreased significantly.

Between 2010 and 2018, the poverty rate of the whole district decreased markedly from $35.30 \%$ to $15.65 \%$ (down $20.35 \%$ ), which is a significant effort of the whole district in the struggle to eradicate poverty. However, despite the significant decrease in the proportion of poor households within 8 years, the proportion of poor households still accounts for a relatively high $15.65 \%$. The disparity between the proportion of poor households in urban and rural areas, the number of poor households in rural areas is nearly 3 times higher than that of poor households in urban areas. In which, the number of poor households is at least in Huong Phong communes (1 household), Phu Vinh (13 households), Son Thuy (16 households); The most poor households belong to Hong Thuy communes (196 households), Hong Van (161 households), A Let (120 households).

Humans one day need to use a lot of energy for the activities of the body and labor. The body's energy consumption is offset by the amount of nutrients from the food provided daily.

A reasonable meal needs to meet the body's complex nutritional requirements for nutrients. In order to have a healthy diet, the most important thing is that the diet meets the needs and balance of nutrients such as proteins, lipids, gluxit, vitamins and minerals. Special cases such as pregnant women, children under 3 years old need to add the amount of kcalo provided daily for good development.

Eating is a basic human need. Improving nutritional conditions is an urgent requirement. However, the economic conditions of the whole country in general and A Luoi district in particular, our goal is to eradicate poverty, improve nutritional quality, proper nutrition and food safety. We have built a reasonable meal structure that ensures sufficient energy and balance of nutritional components (protein, sugar, fat, micronutrients, vitamins).

"Children here are well cared for, but in the structure of their daily meals, they still do not ensure adequate nutrients, there are veryfew fish (meat, fish, eggs ...) mainly vegetables, potatoes, taro and fruits grown in the garden, the children lack milk, only families who are officials or have conditions will have money to buy milk for them". Female government employees of A Dut commune, A Luoi district, Hue Province.

The health care of A Luoi district has made remarkable achievements. The system of facilities from district medical centers to medical stations is basically complete. 21/21 Medical stations are built 2 spacious floors, district Health Center completed phase 2 has been tested and put into use to promote high efficiency. The system of medical equipment is quite fully equipped and modern. At the Medical Center, many new 
machinery equipment is put into use such as endoscopy machines, color ultrasound, semiautomatic bio-testing, electrolyem measurement ... The medical team and doctors throughout the district ensure quantity and quality. Currently, the whole district has 47 doctors and higher qualifications (at the district Medical Center is 19, Medical station 28), medical station 55 (District 18 Medical Center, Medical Station 37), Mid-section 48 (District 14 Medical Center, Medical Station 34) with this team showed that the medical team covered 21/21 medical stations, of which 7 medical stations had 2 doctors. This is unprecedented for the baseline health system. With a fairly well-invested and complete investment from facilities to people, the health sector of A Luoi district constantly attracts patients to medical examination and treatment at medical routes. The average number of visitors is about 150,000 . The capacity of using hospital beds always reaches $100 \%$. At the same time, the health sector has implemented many activities to protect, care for and improve people's health. Communication, health education, medical examination and treatment under health insurance for people, regular health check-up for students, vaccination of children under 1 year old ... are deployed in most communes and towns of the district. Control of infectious diseases, common and emerging epidemic diseases, not let large epidemics occur. Maintain the results of polio payment, exclude newborn tetanus, eliminate measles, expand the use of vaccines to prevent other diseases. Limiting and controlling risk factors for non-infectious diseases, school diseases, environmental diseases, lifestyle, behaviors, food safety and hygiene, nutrition. Promote comprehensive health care, focus on active and proactive prevention, early detection screening and timely treatment of diseases.

Improve the quality of medical examination and treatment services and rehabilitation in all routes. Accelerate the pace of intensive medical development in parallel/simultaneously with universal health. Expanding medical examination and treatment services for local health facilities. Enhances the combination of modern medicine with traditional medicine, prevention and treatment. Private/out-of-public health development, public-private coordination. Improve population quality, maintain reasonable low fertility levels, meet people's family planning needs, increase access to quality birth health services, control the rate of increase in sex ratio at birth; strengthen the integration of population factors into policy planning and socio-economic development plans at all levels and sectors.

Table 1. Crude birth rate, crude death and natural increase of the population of A Luoi district

\begin{tabular}{|c|c|c|c|}
\hline & Raw yield & $\begin{array}{c}\text { Crude mortality } \\
\text { rate }\end{array}$ & $\begin{array}{c}\text { Natural rate of } \\
\text { increase }\end{array}$ \\
\hline $\mathbf{2 0 1 0}$ & 19,1 & 3,7 & 15,4 \\
\hline $\mathbf{2 0 1 1}$ & 18,5 & 3,8 & 14,7 \\
\hline $\mathbf{2 0 1 2}$ & 18,4 & 3,7 & 14,7 \\
\hline
\end{tabular}




\begin{tabular}{|l|l|l|l|}
\hline $\mathbf{2 0 1 3}$ & 19,3 & 3,9 & 15,4 \\
\hline $\mathbf{2 0 1 4}$ & 20,0 & 4,4 & 15,6 \\
\hline $\mathbf{2 0 1 5}$ & 20,3 & 4,6 & 15,7 \\
\hline $\mathbf{2 0 1 6}$ & 20,1 & 4,3 & 15,8 \\
\hline $\mathbf{2 0 1 7}$ & 19,6 & 4,1 & 15,5 \\
\hline $\mathbf{2 0 1 8}$ & 19,4 & 4,0 & 15,2 \\
\hline
\end{tabular}

Source: A Luoi District Statistical Department-2018

Ensure adequate supply of drugs, vaccines, medical bio-products and quality medical equipment at reasonable prices for people's medical examination and treatment needs; use drugs appropriately, safely and effectively; enhance the effectiveness of management and use of medical equipment.

In the past, many households had limited awareness, when there was a disease that only offered ghosts to the forest, so when they were seriously ill, they could not be saved. Now the state gives the village health, the people understand more about health and disease. When sick, go to the doctor, children are vaccinated. Better health should also make more grain, more corn

Male, A Dut commune, A Luoi district, Hue Province

Marriage is a case of early marriage in which the bride and groom or one of them is a child or a person who has not reached the age of marriage (usually less than puberty). In many cases, only one of the two parties is a child, usually a woman for virginity reasons or for reasons that a woman in a certain social community is not considered capable of making money, and because women's fertility quickly ends up than that of men. In Vietnam, according to article 145 of the Criminal Code, "Marriage is two men and women who marry before the age of marriage as prescribed by law i.e. marry before 20 years of age, marry before the age of 18; Those who organize marriages for those under the age of marriage".

The custom of kissing algae both shows the old-fashionedness, the outdated of the outdated orth old-fashioned colors and the weight that inhibits the culture of development. Especially in the current context, the issue of marriage algae also hinders the healthy development of people in general and Ta Oi people in particular, affecting the breed, psycho-psycho-psychology, co-awareness, education, backward poverty, social welfare. In another respect, the problem of marriage also greatly affects the goal of building a new family: equality, progress, warmth, happiness.

Table 2. Kissing algae situation of Ta Oi people in A Dut commune, A Luoi district

\begin{tabular}{|c|c|c|c|c|c|c|c|c|c|c|}
\hline Year & 2009 & 2010 & 2011 & 2012 & 2013 & 2014 & 2015 & 2016 & 2017 & 2018 \\
\hline Case & 3 & 2 & 4 & 4 & 3 & 6 & 2 & 3 & 0 & 0 \\
\hline
\end{tabular}

Source: A Dut Commune People's Committee, quarter I/2019 
Difficulties from marriage: After marrying most of these couples often cannot be independent for their own lives, even if they do not have enough civil act capacity to cover their own lives. There are even couples who are in conflict, living unhappy with each other leading to separation, divorce affecting social order, especially there will be difficulties in terms of property disputes when divorce occurs because they do not have marriage certificates. On the other hand, when these couples give birth, due to their lack of experience as well as knowledge about family life, parenting, it is difficult for babies born to develop comprehensively because they do not receive adequate, attentive care, affecting the quality of the breed as well as socio-economic development. , at the same time, marriage algae will make it difficult for government agencies to manage the population, in the process of implementing and developing socio-economic policies in the locality.

Most of them still live with their parents, how can they eat at a young age? There is also a house after getting married early, then for the refuge but do not know what, come back thanks to parents. Female, government employee, A Dut commune, A Luoi district, Hue Province

In-blood marriage is a marriage between people of the same direct blood. It may be cross-cousin marriage, cousin marriage in parallel with your child/sister marriage. Even in some areas of ethnic minorities, there is still a common form of marriage mating between children - brothers, sisters - sisters in one house. Scientific fact has proven that in visceral marriage creates pathological diving genes in husband and wife combined to produce deformities or geLuoi ic diseases such as color blindness, albinism, white eyebrows, fish skin scales and most seriously congenital hemolysis ... The cause of intubating marriage is the lack of understanding of the people and some ethnic minority couples are influenced by the secular conception.

"Compatriots still take their people for granted, with no shame and wrongdoing. Because, if you marry one of them, your children and grandchildren will keep their wealth from losing to another family. In addition, adults in the house say their children will be more listenable; Nurturing grandparents, parents are alsobetter. However, in fact, due to intural marriage,children often get sick, parents have to take more care, spend money and businesstime". Female, government employee of A Dut commune, A Luoi district, Hue Province

In addition to the difficulties of socio-economic life, in-blood marriage is one of the causes of deterioration of health, increasing the incidence of diseases for babies born, causing a deterioration in the quality of the breed. Although they have used measures to encourage, mobilize and explain to people the problems that their children and grandchildren will face if they marry in the same blood. With modern life today, celebrating human values, personal egos ... intent blood marriage is unacceptable, although it still exists in ethnic minority areas, remote areas and low-er ethnic minority areas. 


\subsection{Malnutrition}

For nutrition for women during pregnancy: The awareness of ta Oi women's nutrition during pregnancy in A Luoi district is not high. The view is that pregnancy and childbirth are a natural problem, so they have not paid attention to the supply of nutrients in the early part of pregnancy, for example they do not know what forms of food to be able to provide adequate nutrients such as protein, sugar, fat, micronutrients ... do not know how to eat to suit the process of pregnancy. Many women who become pregnant in the first 3 months when asked about breakfast say that they are not interested in breakfast because they have to get up early to go to work, so they do not have time to prepare for meals and gradually become a habit without breakfast. For women aged 30 years and older due to limited education and awareness especially about nutrition, it is mainly based on experiences passed down by previous people even though they do not know in these foods what nutrients are good for mothers and fetuses such as eating carp, goose eggs, eating salty food, not eating a lot of vegetables ... For pregnant women between the ages of 20 and 30, awareness is also raised by exposure to mass media but is still influenced by backward customs on pregnancy. They are not aware of the differences between the stages of pregnancy, the amount of nutrients to provide for each stage, they assume that just eat enough, eat more than usual, appetite what is eaten is the fetus will be healthy. They only focus on "fishy substances" such as meat, fish, squid ... especially the habit of eating spices with spicy and sour substances such as chili, pepper, waffle ... not paying attention to greens, fruits, vitamins, milk, iron ... however, due to economic conditions, they could not afford to buy, as well as to cover their lives.

Table 3. Situation of malnourished children in A Dut commune, A Luoi district

\begin{tabular}{|l|c|c|c|c|c|c|}
\hline & \multicolumn{2}{|c|}{$\mathbf{2 0 1 6}$} & \multicolumn{2}{c|}{$\mathbf{2 0 1 7}$} & \multicolumn{2}{c|}{$\mathbf{2 0 1 8}$} \\
\hline Content & $\begin{array}{l}\text { Weight } \\
\text { by age }\end{array}$ & $\begin{array}{l}\text { Advanced } \\
\text { by age }\end{array}$ & $\begin{array}{c}\text { Weight } \\
\text { by age }\end{array}$ & $\begin{array}{c}\text { Advanced } \\
\text { by age }\end{array}$ & $\begin{array}{c}\text { Weight } \\
\text { by age }\end{array}$ & $\begin{array}{c}\text { Advanced } \\
\text { by age }\end{array}$ \\
\hline $\begin{array}{l}\text { Number of children } \\
\text { measured }\end{array}$ & 211 & 211 & 218 & 218 & 207 & 207 \\
\hline male & 101 & 101 & 107 & 107 & 107 & 107 \\
\hline girl of & 110 & 110 & 111 & 111 & 100 & 100 \\
\hline $\begin{array}{l}\text { Number } \\
\text { malnourished } \\
\text { children }\end{array}$ & 63 & 47 & 66 & 34 & 60 \\
\hline male & 24 & 33 & 25 & 39 & 22 & 31 \\
\hline girl & 20 & 30 & 22 & 27 & 12 & 29 \\
\hline Malnutrition rate & $20,9 \%$ & $29,9 \%$ & $21,6 \%$ & $30,3 \%$ & $16,4 \%$ & $29 \%$ \\
\hline
\end{tabular}

Source: A Dinh Commune People's Committee, quarter I/ 2019 
Day3 shows that the proportion of malnourished children over the years is relatively high, from $16.4 \%$ to $30.3 \%$ over the years. With a high rate of malnutrition, there will be an increase in mortality in children under 5 years of age. According to the World Health Organization, 54\% of deaths of children under 5 yearsof age in developingcountries are associated with moderate and mild undernourishment. Malnutrition is a favorable condition for these diseases to occur and last, pathology causes children to eat poorly, energy needs increase and so malnutrition becomes more and more severe. Physical retness: Affects on stature. Lack of nutrition is a direct cause of the decrease in all body systems, including the mesent muscle and bone system, especially when undernutripity occurs early such as malnutrition in the fetal stage and early stages before the child is 2 years old. Malnourished children are also often sluggish to lethargy so social communication is often poor, which entails a decrease in learning and reception. Social risk: Thestature of the nation will be slow to grow if malnutrition has not improved over generations.

In the long run, the physical and intellectual working capacity of malnourished people is undoubtedly affected. Currently, many children reach the age of 15-16 but only like 10-year-olds in the city. I can't say that I'm malnourished and still have the strength to work. The district government is also taking many measures to strengthen and support people in improving nutrition, ensuring sufficient health for productionlabor. Male, A Luoi District Medical Center, Hue City

\section{Discussion}

Ethnic minorities in remote areas are associated with relatively backward customs and difficult living conditions. Therefore, in order to improve the quality of human capital in ensuring sustainable livelihoods for ta Oi ethnic minorities, A Luoi district, Thua Thien Hue province, the government should focus on the following solutions:

\section{Primary health care}

This is an important part of the National Development Strategy, which is the fundamental factor to improve the quality of life of people, families and society as a whole. Identifying the objectives, meaning and importance of health care, the Party and the State always attach great importance to this work, planning to each family at the baseline. This is a highly efficient and low-cost way of care that the community can accept. The goal of health education is to change unhealthy habits and lifestyles that are harmful to health. Education is intended to help people here have the knowledge to protect themselves and strengthen their health. Helping people realize their own habits, lifestyles and habits that are harmful to health, they will practice healthy behaviors on their own. Help people see their responsibilities to themselves and the community. Habits, customs and lifestyles will sometimes be barriers to integration. Health education so that people have health awareness, from here people have appropriate behaviors to their circumstances and living conditions. When there is a sense of public health, people have a sense of preservation and protection for themselves and the community. 
Nutrition education aims to raise public awareness about proper nutrition to ensure the prevention of diseases caused by nutrition. Mobilize the community to solve the problem of nutrition and proper use of locally available food sources, ecosystem development, and barn ponds. Help people know how to organize their own meals properly while ensuring nutrients and suitable for taste.

Child health care and family planning

Promoting education on the population of family planning to make the quality of life of people improve the best, wanting to do this needs to educate people to be aware of the problem of simplifying the population development rate, implementing each family with only 1 to 2 children., promote healthy parenting styles to teach good children. Continue to strive to reduce med mother and child mortality, especially infant mortality. Good solving of nutritional problems for mothers and children. Well-cared for children from within the womb will develop mentally and physically well, which means that the breed is renovated thanks to nutrition. The height and weight of the child is improving thanks to the understanding of parents who have won many special nutrition during pregnancy.

Other tasks: Carry out expanded vaccination to prevent infectious diseases such as diphtheria, whooping cough, tetanus, department, polio. Striving to provide sufficient medicines for the usual prevention and treatment of compatriots at the baseline. Improve the curriculum to suit the requirements of public health, focusing on training industry managers and technical staff. The reasonable structure of the number of doctors, doctors and pharmacists in medical establishments ensures the effectiveness of serving patients. Enhance training by address and have incentive policies for upland officials to work with peace of mind. Diversify training types but ensure quality.

\section{Conclution}

The Ta Oi people in A Luoi district, Thua Thien Hue province have received the attention of the State and authorities at all levels, so the people have had the opportunity to access resources to develop the economy to improve their lives. The study of human factors in the livelihood activities of the Ta Oi people in A Luoi district shows that the life of the people has been gradually improved. The traditional activities of the people are mainly cultivation, livestock, sub-family economy, trade exchange ... along with the progress of society, the traditional life-making practice of the Ta Oi people has changed significantly in structure and scale. Therefore, in production activities, there has been a transition from tourism to settlement, livestock activities have also been developed, making people's incomes more stable. Small crafts are also self-susing, but there has been a focus on restoration to form products for tourism and trade outside, especially brocade weaving and wine cooking. All these livelihood activities need to require the investment of resources of financial, natural, social, material livelihoods and especially most importantly human resources. 


\section{REFERENCES}

Chayanov, A. (1998. ). The New Palgrave Dictionary of Economics. London: Vol.1, Macmillan.

Coleman, J. (1992). Characterization of the Escherichia coli gene for 1-acyl-sn-

glycerol-3-phosphate acyltransferase. March II 1992, Volume 232, Issue 2, pp 295303.

Coleman, J. S. (1988). Social Capital in the Creation of Human Capital. The American Journal of Sociology 94, S95-S120.

Diana Carney. (1998): "Implemeting the Sustainable Livelihood Approach", chapter 1 in D. Carney (ed), Sustainable Rural Livelihoods: What Contribule Can We Make?, London: Department for International Development.

Dasgupta, S. et. al (2007), "The Impact of Seal level Rise on Developing Countries: A Comparative Analysis", World Bank Policy Research Working Paper 4136, February 2007.

DFID (2001), "Susstainable Livelihoods Guidance Sheets”, DFID Report

Tran Thi Mai An. (2005). Livelihoods of the Christians: Accessibility and Opportunities. Hanoi: Social Sciences Publishing House.

Party Committee of A Luoi district. (1996). History of the Party Committee of A Luoi District. Hue: Thuan Hoa Publishing House.

Bui Quang Binh. (2009). Human capital and investment in human capital, Journal of ScienceandTechnology. University of Da Nang, No. 02 (31).

A Luoi District Statistical Department. (2014). Statistical Yearning 2013. Hanoi: National Political Publishing House.

CRD 2006: Sustainable livelihoods in the Central Highlands, Hue University

Do Minh Cuong. (2002). Some issues of human resource development in Vietnam today. Hanoi: Education Nxb. 
Confucius. (2002). "Some population issues with the development of ethnic minorities and mountainous areas in Vietnam", Center for Environmental Resource Research,Hanoi: Hanoi National University.

Nguyen Xuan Hong. (2002). "Livelihoods depend on the forests of the Ta Oi people in Phu Thuong village, Phu Vinh commune, A Luong district, Thua Thien Hue province in the current period", Hue University of Science - Yearning Scientific Seminar: Central - Central Highlands in the process of national unity, innovation and integration.

Nguyen Quoc Loc. (Eds.). (1984). Ethnic minorities in Binh Tri Thien. Hue: Thuan Hoa Publishing House.

Nguyen Van Manh \& cs. (2001). The custom of the Ta Oi, Cu Tu, Bru - Van Kieu people in Quang Tri, Thua Thien Hue. Hue: Thuan Hoa Publishing House.

Shoshana Grossbard (ed.), Jacob Mincer, A Pioneer of Modern Labor Economics. New York: Springer, 2006.

The People's Committee of A Luoi commune. (2018). Summary report on Population planning for families 